\title{
Design of a Minicomputer Separator of Urban Solid Waste (RSU)
}

\author{
Avila Sánchez Ulises \\ Luna Castellanos Luis Felipe \\ Cruz Velasco Rosaluz. \\ González Torres Arturo \\ Marrón Ramos Domingo N. \\ Mendoza Montero Fátima $Y$. \\ Avila Pérez Tagle Alfonso \\ Román Salgado Maximiliano \\ Gutiérrez García Fabiola B. \\ Marín Rangel Nathalia \\ Casarrubias Madrid Francisco $E$.
}

Tecnológico Nacional de Mexico, Instituto Tecnológico de Milpa Alta

Prol. Vicente Guerrero, s/n, San Juan Tepenahuac,

Delegación Milpa Alta. Ciudad de México, México

Doi: 10.19044/esj.2018.c5p19 ～URL:http://dx.doi.org/10.19044/esj.2018.c5p19

\begin{abstract}
In Mexico, the society in general lacks the habit and ethics of properly disposing garbage or in taking care of the environment. This paper focuses on analyzing and disposing garbage in an automated way. The present study also seeks to create and promote care for the planet. The minicomputer (GreenScanProcess) is an automated system whose process is based on an algorithm that stands out for its functionality. GreenScanProcess has sensors that allow the analysis and scanning of garbage. It also measures the weight and humidity of the garbage. The minicomputer also examines the garbage to know its composition. Likewise, GreenScanProcess takes the garbage to the container according to the garbage. The benefits obtained when conducting the research were: environmental, economic, technological, and educational.
\end{abstract}

Keywords: Minicomputer, automated process, algorithm, garbage separation 


\section{Introduction}

Currently, one of the most important concerns of today is garbage, its handling, and its classification in order to improve the natural environment of the world. Bernad (1999) pointed out that the amount of garbage originated is directly proportional to the number of inhabitants. However, in the United States, they generate approximately 750 kilos of garbage in a year per person, while Japan generates approximately 400 kilos of garbage in a year per person. OPS (1988) mentioned that in Latin America, the per capita production of garbage has doubled in the last 30 years, reaching half a kilo per day per person. Aguilar (2008) opined in his article that Mexico has a disgraceful pride of having the largest garbage dump in the world, the Bordo Poniente, located in Ciudad Nezahualcoyotl, Estado of Mexico. Therefore, despite not having space available, the useful life has been lengthened by the difficulty of finding another place to deposit the thousands of tons of garbage produced by the Distrito Federal and its metropolitan area.

Deffis (1994) defines garbage as suggesting dirt, lack of hygiene, bad smell, displeasure at sight, contamination, fecalism, turbidity and impurity. Mora (2004) stated that the word "garbage" means a lot of derogatory words to too many people. It is regarded as something that has no value and what needs to be undone as soon as possible. Silva (2013) pointed out in his work that garbage comprises of the waste of the citizen that he discards on a daily basis by sweeping the front and the inside of his home. Logically speaking, it refers to all types of waste such as those deposited in the bathroom, containers, papers and with all those wastes that leave the home, the office, the street, and the industry.

Flores (2012) indicated that waste is all material, which after having fulfilling its work or having served for a certain task, is discarded. This term is generally used as a synonym for garbage, as it is the broadest word in the language to name all waste discarded by people in their daily work. On the other hand, Alegria (2015) pointed out that the word "solid" is used to designate things and objects, which are presented in a defined form. Panarisi (2015) mentioned that all solid, liquid or gaseous elements that lack economic value for their producer or owner are called residues. However, it is considered that they should be eliminated.

In Mexico City, there is the Environmental Standard NADF-024AMBT 2013 on Separation, Classification, Selective Collection, and Storage of Waste from the Distrito Federal. This norm came into force in July 2017 in order to reduce the amount of garbage that reaches the sanitary landfills and increase the recycling of solid waste (SEDEMA, 2017). Thus, the classification of this standard is as follows (see Figure 1): 


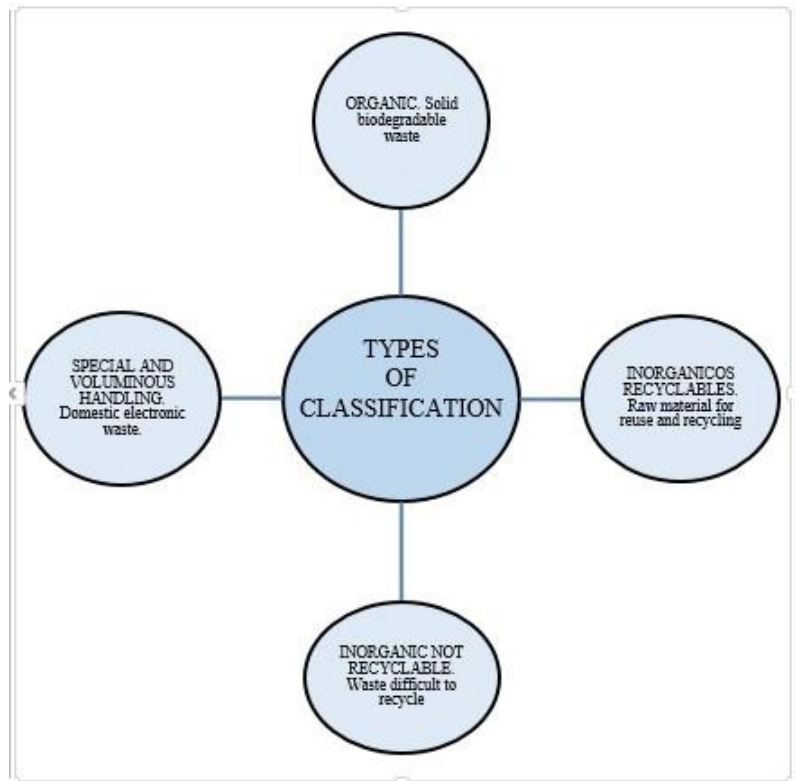

Figure 1. Example of classification of garbage.

Source: Own elaboration.

Lopez (2017) states in his article that the inhabitants of Mexico City only separate 20 percent of the 13 thousand tons that are produced daily in the city. Valdez (2017) stated in his article that the delegations of Iztapalapa, Gustavo A. Madero, and Cuauhtemoc are the delegations that generate majority of the garbage in Mexico City. Notimex of Diario de Yucatan (2017) argued that large amounts of waste are produced every day and it is estimated that around 77 million tons are generated in Mexico each year. This means that during this period, each person generates an average of 300 kilos, of which only 11 percent is recycled. Therefore, this shows that there is still much to be done in that area.

Gongora (2014) cited in his article that one of the biggest obstacles to achieving a significant advancement is based on the fact that the collection and disposal of waste is done within the framework of municipal competencies. Sanchez (2015) argued in his article that the issue of recycling must be from childhood. The writing of Sol de Hidalgo (2017) stated that in Mexico, the issue of recycling and separation of waste is attributed the fact that Mexico lacks the necessary culture to take better advantage of the reuse and treatment of garbage. Romero (2017) pointed out in his article that citizens should be sensitive and aware to understand that the sum of all in these tasks of separation of solid waste will help our environment and the future generation to have a better environment.

With all of the above, this paper focuses on optimizing the processes of separation of solid waste through weight and humidity. It also aims to 
reduce the ecological footprint in the environment based on the percentage of the improvement of the environment, recovery of some spaces, as well as the teaching of recycling, and the reduction of costs at the business level.

\section{General Objective}

Design of a minicomputer separator of urban solid waste (RSU) with the aim of reducing waste and generating awareness in people about caring for the environment.

\section{Justification}

The main objective of this research is to design a process for the separation of solid urban waste in Mexico and taking, as reference, the Environmental Standard NADF-024-AMBT 2013. This will, however, benefit the environment and would in turn have an impact on society. With this, there would be a proper awareness of every inhabitant in this country which will solve the problem at the national level. The importance of our research lies in the environmental, economic, technological, cultural, and social impact.

Altamirano (2016) mentioned in his article that the inhabitants of Mexico City live in an unhealthy environment, not only because of the air pollution, but also because of the poor management that their authorities give to the garbage. Lira (2016) stated that Mexico City is the second with the largest solid waste generation worldwide after New York. This analysis was made based on a study published in the scientific journal Proceedings of the National Academy of Sciences (PNAS).

For this reason, the study of Maldonado (2006), through a program of separation of byproducts, managed to reduce by $67 \%$ the volume of garbage sent to the landfill of the city of Merida. Indústrias Leblan (s / f) developed a device that allows an effective separation of the solid waste that is deposited on it based on its physical characteristics: size, shape, and density. Before the waste is selected (manually or automatically), it must go through this separation called "gravimetric". Subsequently, the present project provides an alternative to achieve a positive change in the environment. With this, there would be a reduction in pollution and people would be able to generate favorable habits towards the environment.

\section{Methodology}

The methodology used for the project was that of Scrum. Bustos (2014) pointed out that it is a methodology that consists of applying a series of good practices, such as separation of roles, team meetings, and reviews. This takes place within a group iterative process, in which partial deliveries 
are made. Also, it has been prioritized with the goal of delivering results quickly.

The stages that were developed were those proposed by Mariño and Alfonzo (2014). Figure 2 represents an example of the aforementioned.

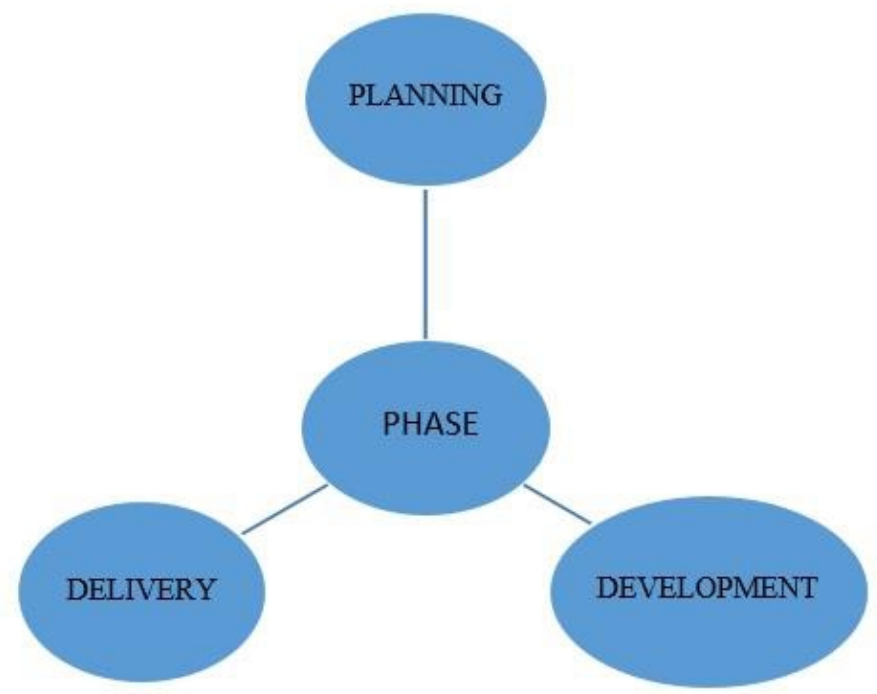

Figure 2. Example of methodology used.

Source: Own elaboration.

Planning: In this stage, the work plan is defined (Navarro, Fernandez \& Morales, 2013). This phase was divided into two:

- $\quad$ Selection of the Area: Through the work of team meetings, the area to work on the research and the sources of information to be consulted was informed. The work team names the project "GreenScannProcess".

- Selection of Viable Topics to be Developed: This stage is characterized for the investigation of materials, competencies, name of the process, brands, author rights, sustainability, state of the art, needs of use, ease of use, target market (market segmentation). The project's image was developed (see Figure 3).

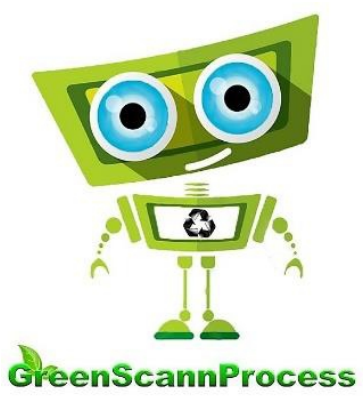

Figure 3. Example of project image

Source: Own elaboration. 
Development: It refers to the lifting of requirements and the system model (Madariaga, Rivero \& Leyva, 2016). An investigation of the properties of the objects was carried out, which will be used for their identification and classification. Thus, it makes use of the different types of correct sensors that are capable of recognizing their individual properties. A diagram of the phases of the process (container states, detection of the sensors, location of the container on the boats, etc.) was also elaborated, optimizing the tasks that are redundant and thus obtaining a maximum performance, and obtaining results in a minimum time to pass for each cycle of this process (for each object classification). Figure 4 represents an example of the prototype of the project.

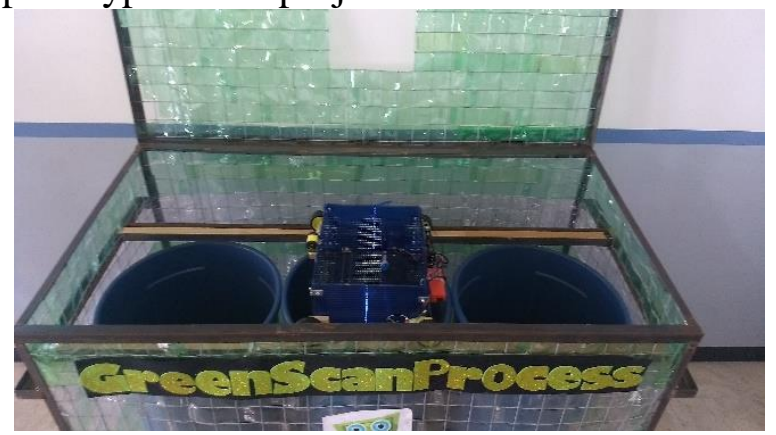

Figure 4. Prototype example.

Source: Own elaboration.

To perform the performance tests, GreenScannProcess was applied in developing a software with a new technology called Raspberry pi 3 . Basically, 3 types of sensors were used: The weight sensor will determine that there is an object in the container that we need to classify; the humidity sensor to identify organic waste; and another sensor to identify recyclable inorganic materials. A cart was developed that contains the system installed, and is able to move in the container in order to classify and deposit the waste in the corresponding boat. Figure 5 represents an example of the operation of the project.

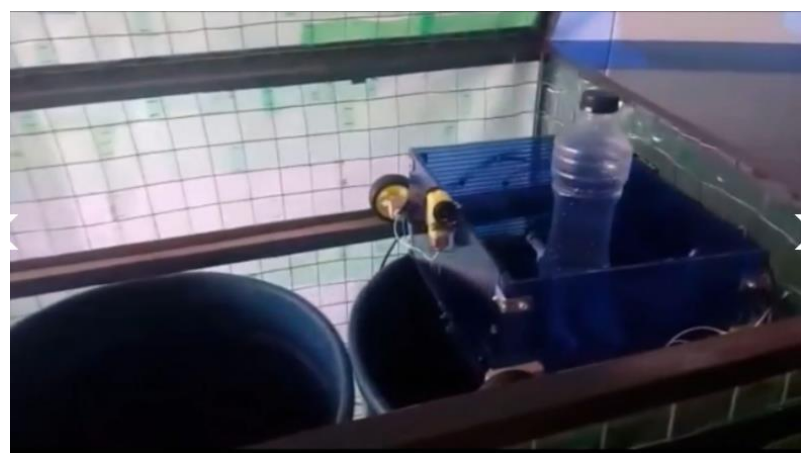

Figure 5. Example of project operation Source: Own elaboration. 
Delivery: This phase is characterized by the finished prototype. The duration of the project was 16 weeks. Figure 6 represents the finished prototype.

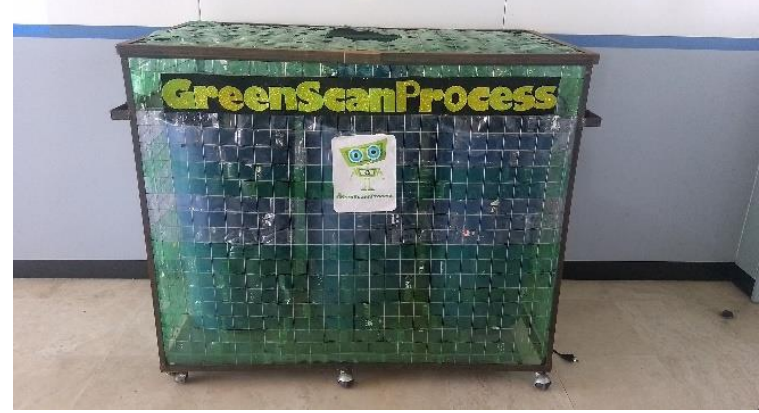

Figure 6. Prototype finished. Source: Own elaboration.

\section{Conclusion}

The overall goal was achieved $100 \%$. The proposal of automatic separator managed to classify the different objects in an expected time of 3 to 5 seconds. The project achieved separation of garbage. Hence, the size of the automatic separator is expected to be improved. This proposal can be the door for several Mexican companies that want to achieve ISO 14001 certification: Environmental management system.

\section{Acknowledgement}

- $\quad$ Rodriguez Cuellar Ruth for her advice on the project.

- Nuñez Cuadra Adriana for her advice on the project.

- Rebolledo Gomez Guadalupe for her advice on the project.

- Instituto Tecnológico de Milpa Alta for his advice on the project.

\section{References:}

1. Aguilar, J. A. (2008). Basura. Entrega Especial. Profeco. Mexico.

2. Alegria López, D. M. (2015). Educación en el manejo de la basura y su incidencia en la prevención de la contaminación del ambiente escolar. Licenciatura en Pedagogía con Orientación en Administración y Evaluación Educativas. Facultad de Humanidades. Universidad Rafael Landívar. Campus de Quetzaltenango.

3. Altamirano, C. (2016). La Ciudad de México no sabe qué hacer con su basura. Ediciones el País S.L.

4. Bernand, J. (1999). Ciencias Ambientales. Francisco Davila. Sexta Edicion. Distrito Federal. Mexico. Pearson.

5. Bustos Velásquez, S. I. (2014). Metodología scrum aplicada a través de un software de consulta de las listas ofac y onu de topbls en las PYME colombianas. Ingeniería de Sistemas. Escuela de Ciencias 
Básicas, Tecnología e Ingeniería. Universidad Nacional Abierta y a Distancia. Bogotá, D.C. Colombia

6. Deffis Caso, A. (1994). La basura en la solución. Árbol Editorial S.A. de C.V. Primera Edición.

7. Flores, J. (2012). Implementación del sistema integral de residuos sólidos urbanos en el distrito de las Lomas. Perú: B-Municipalidad distrital de las Lomas Perú.

8. Gongora Perez, J. P. (2014). El reciclaje en México. Comercio Exterior, vol. 64, núm. 3. Banco Nacional de Comercio Exterior.

9. INDÚSTRIAS LEBLAN S.L. (s/f). Separador balistico. INDÚSTRIAS LEBLAN S.L.

10. Lira, I. (2016). La CdMx, segunda ciudad del mundo que genera más basura; ya no habrá dónde ponerla. Sinembargo.mx

11. Lopez, J. (2017). La CDMX separa sólo 20 por ciento de la basura que produce. Comunidad. Excelsior. Imagen Digital.

12. Madariaga Fernández, C. J., Rivero Peña, Y., \& Leyva Téllez, A. R. (2016). Propuesta metodológica para desarrollo de software educativo en la Universidad de Holguín. Ciencias Holguín, vol. 22, núm. 4, pp. 1-17 Centro de Información y Gestión Tecnológica de Holguín. Holguín, Cuba

13. Maldonado, L. (2006). Reducción y reciclaje de residuos sólidos urbanos en centros de educación superior: Estudio de caso. Volumen 10. Ingeniería Revista Académica de la Facultad de Ingeniería Universidad Autónoma de Yucatán.

14. Mariño, S. I. \& Alfonzo, P. L. (2014). Implementación de SCRUM en el diseño del proyecto del Trabajo Final de Aplicación. Scientia et Technica Año XIX, Vol. 19, No. 4. Universidad Tecnológica de Pereira.

15. Mora Reyes, J. A. (2004). El problema de la basura en la Ciudad de México. Produccion de Estados Urbanos y Metropolitanos.

16. Navarro Cadavid, A., Fernández Martínez, J. D. \& Morales Vélez, J. (2013). Revisión de metodologías ágiles para el desarrollo de software PROSPECTIVA, vol. 11, núm. 2, pp. 30-39. Universidad Autónoma del Caribe.

17. Notimex (2017). Se estima que en México cada habitante genera 300 kilos de basura al año. Mexico. Medio Ambiente. El Diario de Yucatan. Grupo Megamedia.

18. OPS (1988). Manejo de desechos solidos Municipales. Americana Latina. Serie Ambiental.

19. Panarisi, E. A. (2015). Basura Cero, una política pública para el siglo XXI. El caso de la ciudad de Rosario. Escuela de Ciencia Política. 
Facultad de Ciencia Política y RRII. Universidad Nacional de Rosario. Rosario.

20. Redaccion del Sol de Hidalgo (2017). No hay cultura de reciclaje en México. Regional. Organización Editorial Mexicana

21. Romero Herrera, J. (2017). La basura, problema de todos. La Crónica Diaria S.A. de C.V.

22. Sanchez, K. (2015). Reciclar desde la infancia es la solución. Estilo y vida. El debate.

23. SEDEMA (2017). Norma Ambiental NADF-024-AMBT 2013 sobre Separación, Clasificación, Recolección Selectiva y Almacenamiento de los Residuos del Distrito Federal. SEDEMA. Gobierno de la Ciudad de Mexico.

24. Silva Michaca, K. (2013). Analisis urbano arquitectonico de los desechos solidos para implementar una norma en el manejo del mismo en el municipio de Nezahualcoyotl, Estado de Mexico. Escuela Superior de Ingeneria y Arquitectura. Unidad de Tecamachalco. Instituto Politecnico Nacional.

25. Valdez, I. (2017). Tres delegaciones generan la mayor cantidad de basura. Estados: Ciudad de Mexico. Milenio. Grupo Milenio. 